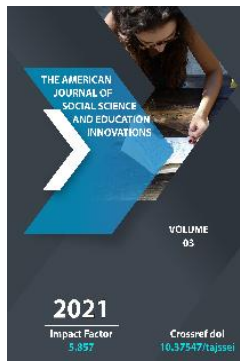

\title{
Concept And Definition Aspects In The International Lexicon
}

Khusniya Bakhtiyorovna Zikrullaeva

PhD In Philology, Tashkent State University Of Oriental Studies, Uzbekistan

Journal Website:

http://usajournalshub.c om/index,php/tajssei

Copyright: Original content from this work may be used under the terms of the creative commons attributes 4.0 licence.

\section{ABSTRACT}

The penetration of international words are clearly reflected on national languages. At present scientific and technical texts cannot be presented without internationalisms since science and technology are in a continuous progress. Some similarities of international lexicon with terms in scientific and technical texts are given in the article. The similarities of internationalisms with terms were studied on the basis of the following criteria: concept and definition. The article also demonstrates the ways of entering new words into languages, how the same words exist in the national language and how they perform on the international level.

\section{KEYWORDS}

Scientific and technical texts, internationalism, concept, term, lexicon, similarity.

\section{INTRODUCTION}

With the development of science and technology internationalism comprehensively penetrates and enriches languages. In accordance with appearance of advanced technologies new words and terms emerge in the world that eventually become understandable in all languages and acquire the title of "internationalism". 
Internationalisms are words that coincide in their external form, i.e. they have phonetic and graphic similarities, and the meanings of such words may coincide in whole or in part. Internationalisms express concepts of international significance and coexist in different languages. One cannot deny the fact that international words are relatively rare in fiction and official business documents. They are mainly found in the media and scientific and technical texts. International vocabulary is widely disseminated through printed publications, television programs, radio programs and social networks. They are the bridges for such vocabulary for all spheres of science.

Internationalisms enter languages through another language or they are created again from the roots of other languages which provide a common foundation for the creation of internationalisms. Widespread languages influenced on many languages of the world. As you know, words and terms of Greek and Latin origin often act as internationalists. In accordance with K. Hergert and T. Alegre [1] who paid great attention to the translation of medical terms, noted words and terms of Greek and Latin origin are aimed at the erudite public, i.e. on professionals, while the vocabulary of national languages is mainly focused on public.

At the same time, internationalisms can enter into languages by borrowing from one language to the other or by borrowing from some third $[2,159]$. This method is the most effective one because the words are transformed into languages in accordance with internal structures. However, to study the international lexis it is necessary to compare and consider it on the materials of two or three languages [3].

\section{MATERIAL}

As a new field of subject knowledge that was formed recently we consider the field of materials science and engineering. This is a very difficult combined work of scientists whose active development has become possible only thanks to research in the fields of physics, chemistry, astronomy, biology and mechanics. When studying the source book "Materials for Engineers and Technicians", the following words of an international character emerged that have similarities in English, Uzbek and Turkish, but they are subject to phonetic adaptation because many of them were borrowed either from Greek and Latin languages or contain elements of these languages that are international terminological elements.

As mentioned above the role of internationalism is very broad in scientific and technical texts. Internationalism has a special place at the international level since their professional function is not limited to one country or one society. Therefore, the periodic table of elements is studied as it is used widely and it was formed at the junction of many scientific directions. Carefully examining the periodic table of elements for internationalisms it turned out that the most productive ending of elements formation is affix -um, which is reproduced in Turkish -yum, and in the Uzbek language - ий which has been transformed from the Russian language. $82 \%$ of all elements from the periodic table of elements are international words since they coincide in the external and internal structure in all three languages, but with minor changes in pronunciation. Of these only $18 \%$ of the elements cannot be considered as international vocabulary because of the peculiar sound in all three languages. It was 
found that $6.5 \%$ of the elements from the total number given in the periodic table of elements have coincidences only in Turkish and English languages and $6.5 \%$ of the elements exist identically in Turkish and Uzbek languages, i.e. they are international words. However, only $5 \%$ of the elements are completely different in all three languages. At present only 104 elements have been studied for percentage ratio because they are famous elements and widely used. But another14 elements have been identified recently. In this regard, all the newly discovered elements in the tables have different names in three languages.

In the Uzbek language there is a process of synonymy in the elements. In terminology, this phenomenon is sometimes perceived as a doublet [4, 127]. A. Madvaliev, scientist in the field of terminology, describes that this process is due to borrowing of Russian terms in Uzbek language and calls them doublets, for example: element as mercury is described as симоб, меркурий, arsenik - маргимуш, мишяк [5, 90-95]. Also, except Russian synonyms in all three languages we can meet Latin origin words as ferrum, aurum, carbon and they are used for studying the formulas. One should note here that the doublets in the terminological system do not share semantic and stylistic groups because emotionalexpressive, stylistic or semantic hues are not felt in terms of doublets. They are peculiar to the literary language. The reason for this, he noted that the serious study of the terminology on the subject of chemistry in the territory of Uzbekistan began in the last century of the 20s, and there was no readymade and systematized terminology for the teaching of chemistry in the Uzbek language.

Nevertheless, it should be recognized that "the doubletness of terms is a kind of synonymy of terms in which terminological words or phrases borrowed from another language are used to designate the same special concept along with the original term or terminological combination" [6, 11]. We cannot ignore the fact that the doublets of terms in synonymic row increase the content of international vocabulary. Internationalisms in scientific and technical texts fulfill the role of terms since they are also used in special texts and are limited to special concepts.

\section{CONCEPT}

Like the terms international words also begin with the concept and occupy one of the central positions. It should be noted that the process of text understanding in foreign language ends by interpretation which forms the recipient's concept, i.e. an accumulation of thoughts where semantic structure and objective meaning of the text are presented [7, 96]. In accordance with the theory of I.N.Volkova concepts are divided into several categories [8, 47]. But when studying international words in scientific and technical texts, we consider the categories of objects to be based on the following attributes: "shape, size, origin, design, purpose, material, chemical composition, manufacturing method, principle of operation, etc.". International words have their own concepts in accordance with the aforementioned features. In confirmation of the foregoing the following examples can be cited on the basis of internationalism in English, Uzbek and Turkish: material: metallic element темирдан (металдан) ясалган элемент-metal element; design: atomic weight -атом оғирлиги-atomun ağırlığı; properties: crystal structure -кристал тузилма-kristal yapı. Regarding this category of evaluation a group of international authors believe that the concept of new words can be defined within 
the established discourse, but it can also create conditions for new concepts [9, 29] under certain social conditions $[10,115]$. Such a pattern is also observed in definitions since the concept and definition are interrelated. Concerning the definition scientists noted that it promotes the process of cognition and communication while concept is in continuous relations and visions of possibilities [11, 159]. Borrowing is also the most effective translation option in which words are transformed in accordance with internal concepts $[12,105]$.

\section{DEFINITION}

Comparing internationalisms with terms it is necessary to pay attention to the definition as well. The definition explains and establishes the meaning of terms. These aspects are related to each other and they are the result in determining the concept. Definition has the least information that is necessary for understanding but it allows us to separate concepts from each other. But the definitions are not stable, over time they can always be changed with the development of science and technology. At first glance, it seems to everyone that the translation of internationalism does not cause difficulties. For example, according to the Dictionary.com, digital dictionary, internationalism, as a generator has five meanings, assimilationseven, corrosion-two meanings, degradationfour meanings. In this connection, the interpreter faces the task of choosing one most appropriate definition in terms of the text and only one of these definitions is the most optimal meaning for interpreting the text.

Moreover, at present international vocabulary penetrates widely into languages. However, this process clearly stands out in scientific and technical texts and fulfills the role of international vocabulary. Of course, one cannot deny the fact that the penetration of foreign vocabulary facilitates the process of translating into languages. Recently, the progress of science and technology is taking place so quickly that the penetration of international vocabulary is accelerating.

\section{REFERENCES}

1. HERGET, K., ALEGRE, T., 2009. Translation of medical terms. Translation Journal. Vol. 13, No. 3, July. http://translationjournal.net/journal/49me dical1.htm.

2. ORLOVA, N., 2013. Sposobi preodoleniya perevodcheskikh oshibok internatsionalnoy psevdointernatsionalnoy leksiki. Innovatsii V obrazovanii. Vestnik Nijegorodskogo universiteta, No. 5(2), p.159.

3. BOBROVNIK, S., 2017. Peculiarities of International Words Translation. Odesskiy linguisticheskiy vestnik. No. 9, vol. 3, p. 50.

4. SHIROKOLOBOVA, A., 2013. Terminologicheskaya sinonimiya na primere russkikh i angliyskikh terminov dambostroyeniya. Voprosi kognitivnoy lingvistiki. No. 3 (036), p. 127.

5. MADVALIEV, A., 2017. Uzbek terminilogiyasi va leksikografiyasi masalalari. Tashkent, p. 90-95.

6. SHELOV, S., 2014. O variativnosti i sinonimii. Izvestiya RAN. Seriya literaturi i yazika. Vol. 73, No. 5, p. 11.

7. MINCHENKOVA, G., 2004. English particles. Spb.:Antology, p. 96. ISBN: 594962-061-5. 
8. VOLKOVA, I, N., 1984. Standartizatsiya nauchno-tekhniheskoy terminologii. Moskow, p. 47.

9. DOLJIKOVA, A., KURILENKO, V., BIRYUKOVA, YU., GLAZOVA, O., ARZUMANOVA, R., 2018. Translationoriented reading of scientific-technical texts vs ordinary reading: psychological and psycholinguistic aspects. XLinguae, vol. 11, issue 2, april, ISSN 1337-8384, elSSN 2453-711X. p. 29

10. DAHLER-LARSEN, P., ABMA, T., BUSTELO, M., IRIMIA, R., KOSUNEN, S., KRAVCHUK, I., MININA, E., SEGERHOLM, CH., SHIROMA, E., STAME, N., TSHALI, CH., 2017. Evaluation, Language, and Untranslatables. American Journal of Evaluation, vol. 38(1), p. 115.

11. OTTE, F., LUIZG, X. deBARROS, 2016. What is the Difference Between a Definition and a Concept? Science Journal of Education, vol. 4 (5), p. 159.

12. OMONOV, K. SH., ZIKRULLAEVA, KH. B., 2020. Nauchno-tekhnicheskiye termini $i$ perevodcheskiye metodi, ispolzovanniye pri ikh sozdanii. Vestnik Chelyabinskogo gosudarstvennogo universiteta \#1 (435), p.105. 